\title{
FOLK MEDICINAL USES OF VERBENACEAE FAMILY PLANTS IN BANGLADESH
}

\author{
Mohammed Rahmatullah ${ }^{1}$, Rownak Jahan ${ }^{1}$, F.M. Safiul Azam ${ }^{1}$, S. Hossan ${ }^{1}$, M.A.H. Mollik ${ }^{1}$, \\ Taufiq Rahman ${ }^{2}$
}

\author{
${ }^{1}$ Department of Biotechnology \& Genetic Engineering, \\ University of Development Alternative, Dhanmondi, Dhaka-1205, Bangladesh. \\ ${ }^{2}$ Department of Pharmacology, University of Cambridge, Tennis Court Road CB2 1PD, \\ Cambridge, UK \\ *Email: rahamatm@hotmail.com
}

\begin{abstract}
Folk medicinal practitioners form the first tier of primary health-care providers to most of the rural population of Bangladesh. They are known locally as Kavirajes and rely almost solely on oral or topical administration of whole plants or plant parts for treatment of various ailments. Also about $2 \%$ of the total population of Bangladesh are scattered among more than twenty tribes residing within the country's borders. The various tribes have their own tribal practitioners, who use medicinal plants for treatment of diseases. The objective of the present survey was to conduct an ethnomedicinal survey among the Kavirajes and tribal practitioners to determine which species of plants belonging to the Verbenaceae family are used by the practitioners. The Verbenaceae family plants are well known for constituents having important bio-active properties. The present survey indicated that 13 species belonging to 8 genera are used by the folk and tribal medicinal practitioners of Bangladesh. A comparison of their folk medicinal uses along with published reports in the scientifie literature suggests that the Verbenaceae family plants used in Bangladesh can potentially be important sources of lead compounds or novel drugs for treatment of difficult to cure debilitating diseases like malaria and rheumatoid arthritis.
\end{abstract}

Key words: Verbenaceae, folk medicine, Bangladesh, medicinal plants

\section{Introduction}

The Verbenaceae family of plants, which is also commonly known as the verbena or vervain family consists of trees, shrubs and herbs. They are mainly flowering plants found in the tropical regions of the world. The family includes some 35 genera and around 1,200 species.

The Verbenaceae family plants are well known for their uses in the traditional medicinal systems of various countries. Quite a number of the plants have been reported to contain bio-active phytochemicals with important pharmacological effects. To cite only a few recent publications, abietane diterpenoids having anti-microbial and anti-parasitic (anti-leishmanial, anti-malarial) properties have been isolated from the roots of Clerodendrum eriophyllum Gürke (Machumi et al., 2010). Ethanolic extract of Premna corymbosa (Burm.f.) Rottl. \& Willd. leaves reportedly suppressed the development of chronic arthritis in rats induced by Complete Freund's Adjuvant (Karthikeyan and Deepa, 2010).

Essential oil obtained from leaves of Lippia gracilis Schauer reportedly possessed antinociceptive and antiinflammatory activities. Notably the plant is used by folk medicine practitioners of the Caatinga region of Northeastern Brazil for these properties (Mendes et al., 2010). Essential oil obtained from Lippia graveolens Kunth reportedly inhibited the growth of Giardia lamblia, the causative agent for the diarrheal disease, giardiasis (Machado et al., 2010). Anti-oxidant and cytotoxic activity of essential oil from leaves and fine stems of Lippia schomburgkiana Schauer (main constituents 1,8-cineole and $\alpha$ terpineol) has been demonstrated (da Silva et al., 2009). Essential oils obtained from Lippia turbinata Griseb. and Lippia polystachya Griseb. reportedly demonstrated lethal effects against mosquito larvae of Culex quinquefasciatus, where ambulation speed and total time of ambulation was significantly decreased (Kembro et al., 2009). Essential oil of Lippia sidoides Cham. has been shown to have anthelmintic activity against sheep gastrointestinal nematodes (Camurça-Vasconcelos et al., 2007; CamurçaVasconcelos et al., 2008). Anti-spasmodic activity has been reported for essential oil from Lippia dulcis Trev., a plant used in traditional medicine of Central America for cough, colds, bronchitis, asthma, and colic (Görnemann et al., 2008).

A new anthraquinone, named tectone (3,8-dihydroxy-2-methyl anthraquinone) with anti-hyperglycemic properties has been isolated from leaves of Tectona grandis L.f. (Shukla et al., 2010). Essential oils obtained by hydrodistillation of Aloysia polystachya (Griseb.) Moldenke and Aloysia citriodora Ortega ex. Pers. have been reported to have ovicidal activity against eggs and second instar nymphs of the soybean pest Nezara viridula (Hemiptera: Pentatomidae). The major components in the oil were carvone for A. polystachya, and citronellal and sabinene for A. citriodora (Werdin González et al., 2010). Pro-apoptotic activity of essential oil from Verbena officinalis L., and its main component citral has been reported in experiments conducted with lymphocytes collected from patients with chronic lymphocytic leukemia (De Martino et al., 2009). Anti-oxidant and anti-fungal properties have been shown of various solvent extracts of leaves of V. officinalis (Casanova et al., 2008). 
Ethanol extract of Stachytarpheta jamaicensis (L.) Vahl reportedly demonstrated anti-inflammatory properties in animal models of nociception and inflammation (Sulaiman et al., 2009). Anti-inflammatory phenylpropanoid glycosides have been reported from leaves of Clerodendron trichotomum Thunberg (Kim et al., 2009). The plant, Clerodendrum umbellatum Poir is used in the traditional medicinal system of Cameroon for treatment of intestinal helminthiasis; aqueous extract of leaves have been shown to demonstrate schistosomicidal properties in Schistosoma mansoni mice model (Jatsa et al., 2009). Another plant, Acantholippia deserticola (Phil.) Moldenke, used in traditional northern Chilean medicine, has been shown to have anti-oxidant properties (Morales et al., 2008).

Bangladesh has a rich tradition of alternative medicinal practices, which include homeopathy, Ayurvedic, Unani, and folk medicine. The latter is practiced by folk medicinal practitioners known commonly as Kavirajes, who rely almost exclusively on medicinal plants for treatment of various ailments. The mode of plant usage is simple, being decoctions, pastes or macerations of whole plant or plant parts followed by topical or oral administration. The Kavirajes tend to keep the knowledge within the family and which is passed from generation to generation. As a result, the Kavirajes over hundreds of years have accumulated considerable knowledge on medicinal plants of Bangladesh. Almost every Kaviraj has his unique repertoire of medicinal plants, and as such, the use of medicinal plants for treatment of a given ailment may differ between Kavirajes of even adjoining villages. Villages form the primary unit of human habitation in the country and almost every village has one or two practicing Kavirajes, who in turn form the primary health-care providers to the inhabitants. This is more so because the villagers not only lack modern medicinal facilities but also most of the time, they cannot afford the price of modern allopathic drugs. Moreover, since the Kavirajes reside within the village, the rural people feel more comfortable to discuss with the Kayirajes their health problems.

About $2 \%$ of the population of Bangladesh are scattered among more than twenty tribes within the country. The tribal medicinal practitioners also rely on medicinal plants for treatment of various diseases. Even as of this date, the tribal people obtain primary health-care from their own practitioners instead of visiting allopathic doctors, who are in reality absent from most of the tribal villages.

We had been conducting ethnomedicinal surveys in numerous villages and among various tribes of Bangladesh over the last few years (Hossan et al., 2010; Mollik et al., 2010; Rahman et al., 2010; Rahmatullah et al., 2010 a-i). In our ethnomedicinal surveys we noticed that Verbenaceae family plants hold considerable importance with the Kavirajes for treatment of a considerable number of ailments. The objective of this review is to describe the use of Verbenaceae family plants by the Kavirajes and tribal practitioners of Bangladesh.

Materials and methods

The population of Bangladesh is quite homogenous with about $98 \%$ of the people speaking the Bengali language. The majority of the population resides in the 86,000 villages and small towns of the country. The number of large cities is only four with only two cities, namely Dhaka and Chittagong, which can be considered as major cities with modern health care facilities and a sizeable number of allopathic doctors. About $2 \%$ of the total population are scattered among the various tribal populations of the country, who reside mainly in the south-eastern, north-eastern, and northern regions of the country. Ethnomedicinal surveys were conducted among the Kavirajes, randomly selected from various villages of the 64 districts of Bangladesh. Surveys were further conducted among the major and some minor tribes of the country, which included the Garos, Santals, Manipuris, Chakmas, Marmas, Chaks, Tonchongas, Rakhains, Murongs, Tripuras, and the Khasias.

All surveys were conducted with the help of a semi-structured questionnaire and the guided field-walk method as described by Martin (1995) and Maundu (1995). Briefly, informed consent was first obtained from the Kavirajes and tribal medicinal practitioners. The objective of the survey was explained and consent obtained that the results may be disseminated nationally and internationally. Where tribes were concerned, actual surveys were conducted through an interpreter, who usually happened to be the Headman of the tribe and conversant in both the tribal language as well as Bengali. Kavirajes took the interviewers in field-walks to places from where they collected their medicinal plants, pointed out the plants and described their uses. All plant specimens were collected on the spot, dried and later brought back to the Bangladesh National Herbarium at Dhaka for proper identification. Occasionally, we relied on Mr. Manzurul Kadir Mia, ex-Principal Scientific Officer and Curator of the Bangladesh National Herbarium for plant identification. Information obtained from the Kavirajes and tribal medicinal practitioners during daytime field-walks were cross-checked in evening meetings with the practitioners and any other interested person of the village present at those meetings.

\section{Results}

The various surveys conducted among Kavirajes and different tribes of Bangladesh indicated that altogether 13 species distributed into 8 genera of Verbenaceae family plants are used by the folk medicinal and tribal medicinal practitioners within the country. Four plants belonged to the Clerodendrum genus, while two plants belonged to the Lippia genus. From the number of ailments treated and citations by the Kavirajes, Clerodendrum viscosum was the most frequently used plant followed by Clerodendrum indicum and Nyctanthes arbor tristis. Rheumatoid arthritis and skin diseases appeared to be the ailments for which the Clerodendrum genus was used for treatment. The results are summarized in Table 1.

The various plant parts used for treatment included whole plants, leaves, roots, stems, barks, meristems, flowers, fruits, and seeds. Of the various plant parts used, leaves constituted the majority of uses ( $26.7 \%$ of total uses), followed by whole plants $(15.6 \%)$, roots and stems $(13.3 \%$ each), barks and flowers $(11.1 \%$ each), fruits $(4.4 \%)$, seeds and meristems $(2.2 \%)$. Whole plant, individual plant parts, as well as a combination of plant parts were observed to be used for treatment of various ailments. For instance, whole plants of Clerodendrum indicum were used for treatment of coughs, rheumatoid arthritis, jaundice, skin diseases, 


\begin{tabular}{|c|c|c|c|c|}
\hline $\begin{array}{c}\text { Serial } \\
\text { number }\end{array}$ & Botanical name & Local name(s) & Plant part(s) used & Ailment(s) treated and plant part(s) used \\
\hline 1 & $\begin{array}{l}\text { Callicarpa japonica Thunb. ex } \\
\text { Murray }\end{array}$ & Rakabbory & Leaf & Dyspepsia, heart burn (leaf). \\
\hline 2 & Callicarpa macrophylla Vahl. & $\begin{array}{l}\text { Jama-thoi (Tripura tribe) }{ }^{1} \text {, } \\
\text { Kanili-shar }\end{array}$ & Whole plant, root & $\begin{array}{l}\text { Tonic, dermatitis, cancer, antidote to poison (whole plant). } \\
\text { Heart palpitations, frequent diarrhea (Tripura tribe) (root). }\end{array}$ \\
\hline 3 & $\begin{array}{l}\text { Clerodendrum indicum (L.) } \\
\text { Kuntze }\end{array}$ & $\begin{array}{l}\text { Brahmon-hati, Bamon hati, } \\
\text { Bamon-haki, Dibjja phool, } \\
\text { Raaz-biit, vamot gach, Vamut, } \\
\text { Bine josthi, Biaich gach } \\
\text { (Tripura tribe), Bamus gach } \\
\text { (Garo tribe), Meremmo } \\
\text { (Rakhain tribe) }\end{array}$ & $\begin{array}{l}\text { Whole plant, leaf, } \\
\text { root, bark, stem }\end{array}$ & $\begin{array}{l}\text { Cough, rheumatoid arthritis, jaundice, skin diseases, edema, sedative, } \\
\text { cancer, diabetes, boils, asthma (whole plant). } \\
\text { Skin lesions on children's throat, measles in children, to remove spots } \\
\text { or scars from face and body (Tripura tribe), skin rash (Garo tribe), } \\
\text { whooping cough, allergy, abscess (leaf). } \\
\text { Eczema, itches, toothache (Rakhain tribe) (stem). } \\
\text { Cold, asthma, respiratory problems, bloating, tuberculosis (root). } \\
\text { Diseases of the fetus, excessive menstrual bleeding (leaf + root). } \\
\text { Skin disorders (Rakhain tribe) (leaf + bark). } \\
\text { Gastrointestinal problems, respiratory problems like cough, asthma, } \\
\text { swellings in any portion of the body (Rakhain tribe) (leaf + root or } \\
\text { leaf + bark or root + bark). } \\
\text { Respiratory distress, herpes, skin and soft tissue infections (leaf + } \\
\text { stem + root). } \\
\text { Syphilis, edema, rheumatoid arthritis, asthma, colic (leaf + root + } \\
\text { bark). }\end{array}$ \\
\hline 4 & $\begin{array}{l}\text { Clerodendrum inerme (L.) } \\
\text { Gaertn. }\end{array}$ & Vana-jhai & & $\begin{array}{l}\text { Night blindness, pneumonia, colic, rheumatoid arthritis (leaf + } \\
\text { flower). }\end{array}$ \\
\hline 5 & $\begin{array}{l}\text { Clerodendrum trichotomum } \\
\text { Thunb. ex Murray }\end{array}$ & Chapa-genda & eaf, stem, flower & $\begin{array}{l}\text { Heart diseases, rheumatoid arthritis, skin diseases (leaf + stem + } \\
\text { flower). }\end{array}$ \\
\hline 6 & Clerodendrum viscosum Vent. & $\begin{array}{l}\text { Viti, Bhat pata, Bhati, Vaita, } \\
\text { Foksha, Bandi gach, Baad- } \\
\text { bagora, Veter gach, Bite gaeh or } \\
\text { Kung-sroi-ma (Tripura tribe), } \\
\text { Oli-phang (Chak tribe), Ghatho } \\
\text { or Tikto-bhat (Santal tribe), vati } \\
\text { or Bhat or Baita gach or } \\
\text { Shamtakari-phang (Garo tribe), } \\
\text { Bite gach (Manipuri tribe), } \\
\text { Wakk-ram (Murong tribe), Go- } \\
\text { mokha (Rakhain tribe) }\end{array}$ & $\begin{array}{l}\text { Whole plant, leaf, } \\
\text { stem, meristem, root, } \\
\text { flower, fruit }\end{array}$ & $\begin{array}{l}\text { Giddiness, typhus, colic in cattle, diabetes, fever, cold, aphrodisiac, } \\
\text { malaria, helminthiasis, insect repellent, itches, coughs, infections, } \\
\text { tonic, gastritis, dermatitis, dysentery (whole plant). } \\
\text { Stomach ache, acidity, bloating (Chak tribe), frequent fever, muscle } \\
\text { ache, joint ache, gastrointestinal discomfort (Garo tribe), stomach } \\
\text { ache (Marma tribe), stomach ache (Manipuri tribe), jaundice, } \\
\text { toothache, helminthiasis, spinal pain, fracture or strain, fever, } \\
\text { diabetes, coughs, asthma, skin diseases, snake bite, stomach pain, } \\
\text { acidity, stimulation of appetite, diarrhea in cattle, lesions within the } \\
\text { ear, toothache, malaria fever, typhoid, rheumatic fever, dengue fever, } \\
\text { head lice, infections from scorpion bites, nausea, vomiting, puerperal } \\
\text { fever, frequent urination (leaf). } \\
\text { Blood dysentery, dysentery (stem). } \\
\text { Feeling of weakness during time of menstruation (Tripura tribe), } \\
\text { gonorrhea, low semen count, leukorrhea, pain, allergy (root). } \\
\text { Redness of eye (meristem). } \\
\text { Acidity, diabetes, jaundice, peptic ulcer, dysentery, fever in children, } \\
\text { toothache, gum ache (leaf + stem). }\end{array}$ \\
\hline
\end{tabular}




\begin{tabular}{|c|c|c|c|c|}
\hline & & & & $\begin{array}{l}\text { Gastritis, jaundice, diabetes, skin eruptions, fever, dysentery, diarrhea } \\
\text { or wound in cattle (Santal tribe), malaria, dermatitis, myopathic } \\
\text { spasm, boils on the head or body of children, scabies, eczema, } \\
\text { urinary problems, gastrointestinal tract problems, malaria, } \\
\text { helminthiasis, coughs, typhus, hepatitis, pain, fever (leaf + root). } \\
\text { Scorpion sting, jaundice, skin diseases, stomach disease (leaf + } \\
\text { flower). } \\
\text { Helminthiasis, diarrhea (leaf + fruit). }\end{array}$ \\
\hline 7 & Duranta repens L. & $\begin{array}{l}\text { Kata-mehandi, Kata-mehendhe } \\
\text { (Garo tribe) }\end{array}$ & $\begin{array}{l}\text { Whole plant, leaf, } \\
\text { fruit, bark }\end{array}$ & $\begin{array}{l}\text { Insect repellent, itches, infertility, fever, pneumonia, antidote to } \\
\text { poisoning, neuralgic disorder, malaria (whole plant). } \\
\text { Malarial fever (Garo tribe) (bark). } \\
\text { Malarial fever (Garo tribe (leaf + fruit). }\end{array}$ \\
\hline 8 & Lantana camara L. & Chaturaangi, Jangoli-janglog & $\begin{array}{l}\text { Whole plant, leaf, } \\
\text { root, flower }\end{array}$ & $\begin{array}{l}\text { Cough, mental diseases, fever, boils (whole plant). } \\
\text { Tuberculosis, malaria, small pox, fistula, tetanus, tumor (leaf + root } \\
+ \text { flower }\end{array}$ \\
\hline 9 & $\begin{array}{l}\text { Lippia alba (Mill.) N.E.Br. ex } \\
\text { Britton \& P. Wilson }\end{array}$ & Khuria & Leaf & Cuts and wounds (leaf). \\
\hline 10 & Lippia nodiflora (L.) Michx. & $\begin{array}{l}\text { Bhumi-okra, Saitta okra, Okra } \\
\text { pata, Khoi-upra, Horinga lota }\end{array}$ & & $\begin{array}{l}\text { Constipation, eczema, heat stroke, rheumatoid arthritis, nervous } \\
\text { disorders, gonorrhea, fever, boils, pain, spasms (whole plant). } \\
\text { Headache, fever, dizziness (leaf + stem). } \\
\text { Pain due to working or falling down, pain in back or waist due to } \\
\text { rheumatism (leaf + stem + bark). }\end{array}$ \\
\hline 11 & Nyctanthes arbor tristis L. & $\begin{array}{l}\text { Shefali, Sheuli, Sheuly-phang } \\
\text { (Garo tribe) }\end{array}$ & $\begin{array}{l}\text { Whole plant, leaf, } \\
\text { stem, root, bark, }\end{array}$ & $\begin{array}{l}\text { Influenza, dandruff, helminthiasis (whole plant). } \\
\text { Fever, coughs, mucus, rheumatism, hypertension, diabetes, obesity, } \\
\text { dandruff, migraine, malaria (leaf). } \\
\text { Constipation in children (flower). } \\
\text { Constipation in children (seed). } \\
\text { Expectorant (leaf + bark). } \\
\text { Arthritis, malaria, expectorant (leaf + bark of root). } \\
\text { Fever, coughs (leaf + flower). } \\
\text { Dog bite, cancer, ecbolic, flatulency (leaf + stem + flower). } \\
\text { Bacterial infections, fungal infections, inflammation, helminthiasis, } \\
\text { biliary problems, obstinate remittent fever, constipation in children, } \\
\text { sciatica, rheumatoid arthritis, alopecia (leaf + bark + flower + seed). }\end{array}$ \\
\hline 12 & Premna integrifolia L. & & Leaf, bark, root & $\begin{array}{l}\text { Fever (leaf). } \\
\text { Fever, energy stimulant (leaf + bark + root) }\end{array}$ \\
\hline 13 & $\begin{array}{l}\text { Stachytarpheta indica (L.) } \\
\text { Vahl. }\end{array}$ & Supang & Leaf, stem & Leukorrhea (leaf + stem) \\
\hline
\end{tabular}

${ }^{1}$ All local names are in Bengali language unless a specific tribe is mentioned. 
Table 2. Some reported bio-activities of Verbenaceae family plants used by folk and tribal medicinal practitioners of Bangladesh.

\begin{tabular}{|c|c|}
\hline Plant & Scientific literature on bio-activity studies \\
\hline Callicarpa japonica Thunb. ex Murray & $\begin{array}{l}\text { Free radical scavenging activity reported for lignan glycosides isolated from stems of the plant (Ono et al., 2009). } \\
\text { Insect repellent terpenoids - callicarpenal and intermedeol reported from leaves (Chen et al., 2008); isolation of Aedes aegypti and } \\
\text { Anopheles stephensi mosquito bite deterrent terpenoids - } \alpha \text {-humulene, humulene epoxide II, intermedeol, and spathulenol from the } \\
\text { plant (Cantrell et al., 2005). } \\
\text { Anti-bacterial activities reported against Bacillus cereus and Salmonella typhimurium for volatile constituents (1-octen-3-ol, 2-hexenal) } \\
\text { isolated from the plant (Kim and Shin, 2004). } \\
\text { Anti-viral activity reported for a flavone isolated from the plant-5,6,7-trimethoxyflavone against herpes simplex virus type 1, human } \\
\text { cytomegalovirus, and poliovirus (Hayashi et al., 1997). }\end{array}$ \\
\hline Callicarpa macrophylla Vahl. & $\begin{array}{l}\text { Betulinic acid has been reported from the plant (Pan et al.,2008), which is known to have anti-plasmodial properties (Steele et al., } \\
\text { 1999). } \\
\text { Extract of bark shown to inhibit lipid peroxidation in biological membranes (Kumar and Müller, 1999); }\end{array}$ \\
\hline Clerodendrum inerme (L.) Gaertn. & $\begin{array}{l}\text { Significant antinociceptive activity reported for alcoholic and aqueous extracts of leaves (Parveen et al., 2010). Hepatoprotective } \\
\text { activity demonstrated by ethanolic extract of leaves against carbon tetrachloride-induced liver damage in Swiss albino rats (Gopal and } \\
\text { Sengottuvelu, 2008). } \\
\text { An anti-plasmodial compound, betulinic acid reportedly present in the plant (Pandey et al., 2007). Chemopreventive and anti- } \\
\text { lipidperoxidative properties reported for ethanolic extract of leaves against 7,12-dimethylbenz(a)anthracene-induced skin } \\
\text { carcinogenesis in Swiss albino mice (Renju et al., 2007), and hamster buccal pouch carcinogenesis (Manoharan et al., 2006). }\end{array}$ \\
\hline $\begin{array}{l}\text { Clerodendrum trichotomum Thunb. ex } \\
\text { Murray }\end{array}$ & $\begin{array}{l}\text { Anti-inflammatory phenylpropanoid glycosides reported from leaves (Kim et al., 2009); leaf extract shown to provide anti- } \\
\text { inflammatory effects through inhibiting pro-inflammatory gene expression in lipopolysaccharide-stimulated RAW } 264.7 \text { macrophages } \\
\text { by suppressing NF-kB activation (Park and Kim, 2007); anti-oxidative phenylpropanoid glycoside, trichotomoside reported from the } \\
\text { plant with radical scavenging property and ability to protect viability of Chinese hamster lung fibroblasts (V79-4) cells exposed to } \\
\text { hydrogen peroxide and } \gamma \text {-irradiation (Chae et al., 2006); reported anti-inflammatory property of acteoside, a phenylpropanoid glycoside } \\
\text { isolated from the plant, as demonstrated by inhibition of arachidonic acid release and prostaglandin E2 production induced by mellitin } \\
\text { in RBL-2H3 mast cells (Lee et al., 2006); anti-oxidant activity reported for jionoside D, a constituent of the plant (Chae et al., 2004); } \\
\text { anti-inflanmatory properties reported for methanol extract of leaves in rats, mice, and RAW 264.7 cells (Choi et al., 2004); anti- } \\
\text { oxidant activity reported for isoacteoside, a constituent isolated from the plant (Chae et al., 2005). } \\
\text { Reported inhibition of oesophagitis and gastritis in rats by apigenin-7-O- } \beta \text {-D-glucuronopyranoside, a constituent of leaves of the plant } \\
\text { (Min et al., 2005). } \\
\text { Phenylpropanoid glycosides - acteoside, leucosceptoside A, martynoside, acteoside isomer, and isomartynoside isolated from ethyl } \\
\text { acetate extract of the plant with anti-hypertensive effects as demonstrated by significant inhibition of angiotensin converting enzyme } \\
\text { (Kang et al., 2003). }\end{array}$ \\
\hline Duranta repens L. & $\begin{array}{l}\text { Mosquitocidal triterpenes, } \beta \text {-amyrin and 12-oleane } 3 \beta, 21 \beta \text {-diol, which have larvicidal properties against larvae of Culex } \\
\text { quinquefasciatus have been isolated from stems (Nikkon et al., 2010); flavonoid glycosides demonstrating anti-plasmodial activity } \\
\text { against chloroquine-sensitive (D6) and chloroquine-resistant (W2) strains of Plasmodium falciparum reported from chloroform soluble }\end{array}$ \\
\hline
\end{tabular}




\begin{tabular}{|c|c|}
\hline & $\begin{array}{l}\text { fraction of whole plant (Ijaz et al., 2010); triterpene saponins with significant cytotoxic activity against HepG2 cell line reported } \\
\text { (Ahmed et al., 2009), along with oleanolic acid, which reportedly possess anti-plasmodial activity (Moon et al., 2007; van Baren et al., } \\
\text { 2006); anti-malarial effects noted for ethyl acetate and aqueous extracts of fruits against Plasmodium berghei (Castro et al., 1996). } \\
\text { Anti-oxidative coumarinolignoids, repenins A-D reported from chloroform soluble fraction of whole plant (Ahmad et al., 2009); } \\
\text { presence of acteoside reported in the plant, which has anti-oxidant activity (Shahat et al., 2005). } \\
\text { Report of } \alpha \text {-glucosidase inhibitory constituents from the plant, suggesting the plant's anti-diabetic potential (Iqbal et al., 2004). }\end{array}$ \\
\hline Lantana camara $\mathrm{L}$. & 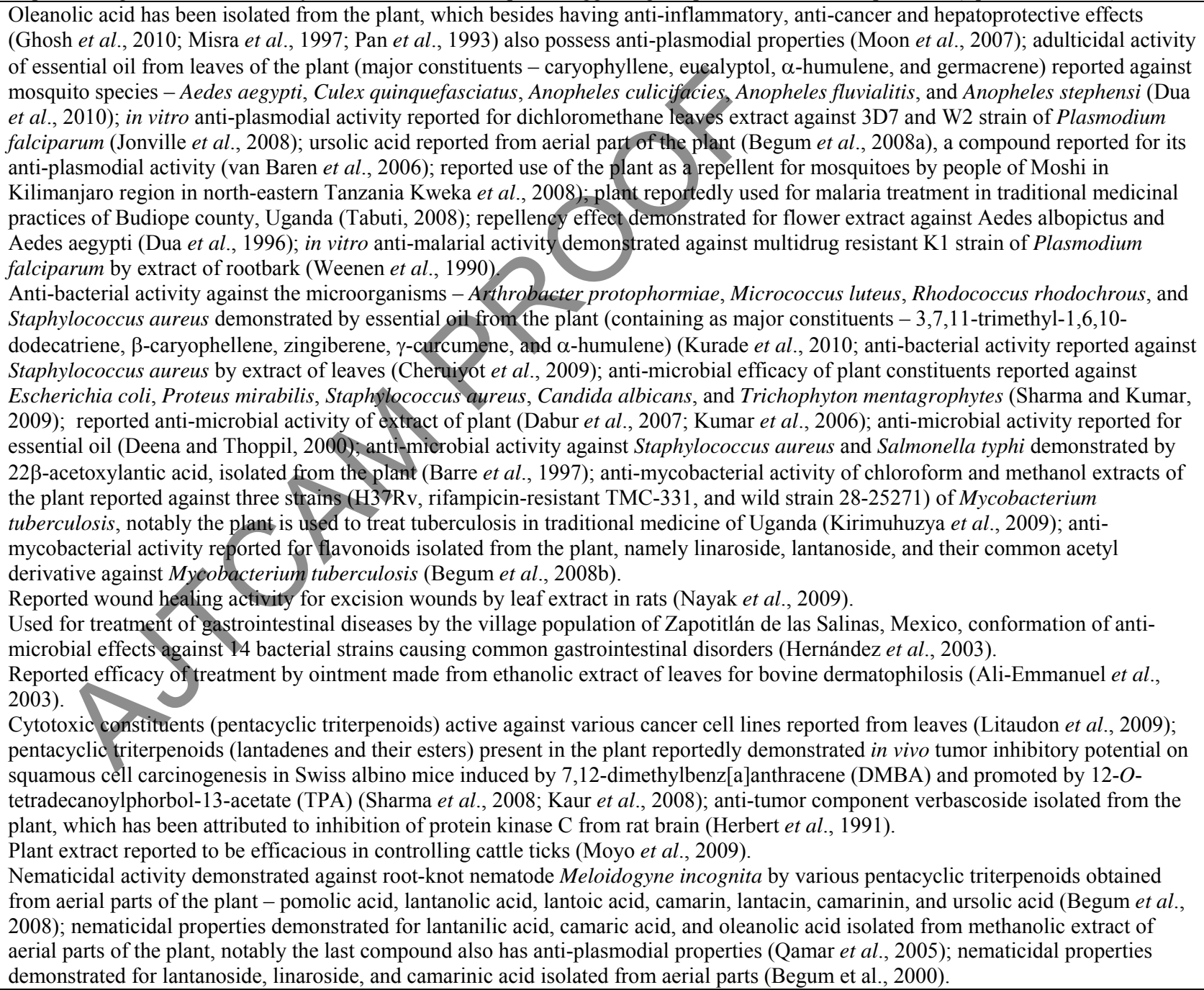 \\
\hline
\end{tabular}




\begin{tabular}{|c|c|}
\hline & $\begin{array}{l}\text { Anti-filarial activity demonstrated by stem extract against human lymphatic filariid Brugia malayi and rodent filariid } \\
\text { Acanthocheilonema viteae (Misra et al., 2007). } \\
\text { Insecticidal activity reported of volatile oils from leaves and flowers (Abdel-Hady et al., 2005). }\end{array}$ \\
\hline $\begin{array}{l}\text { Lippia alba (Mill.) N.E.Br. ex Britton \& } \\
\text { P. Wilson }\end{array}$ & 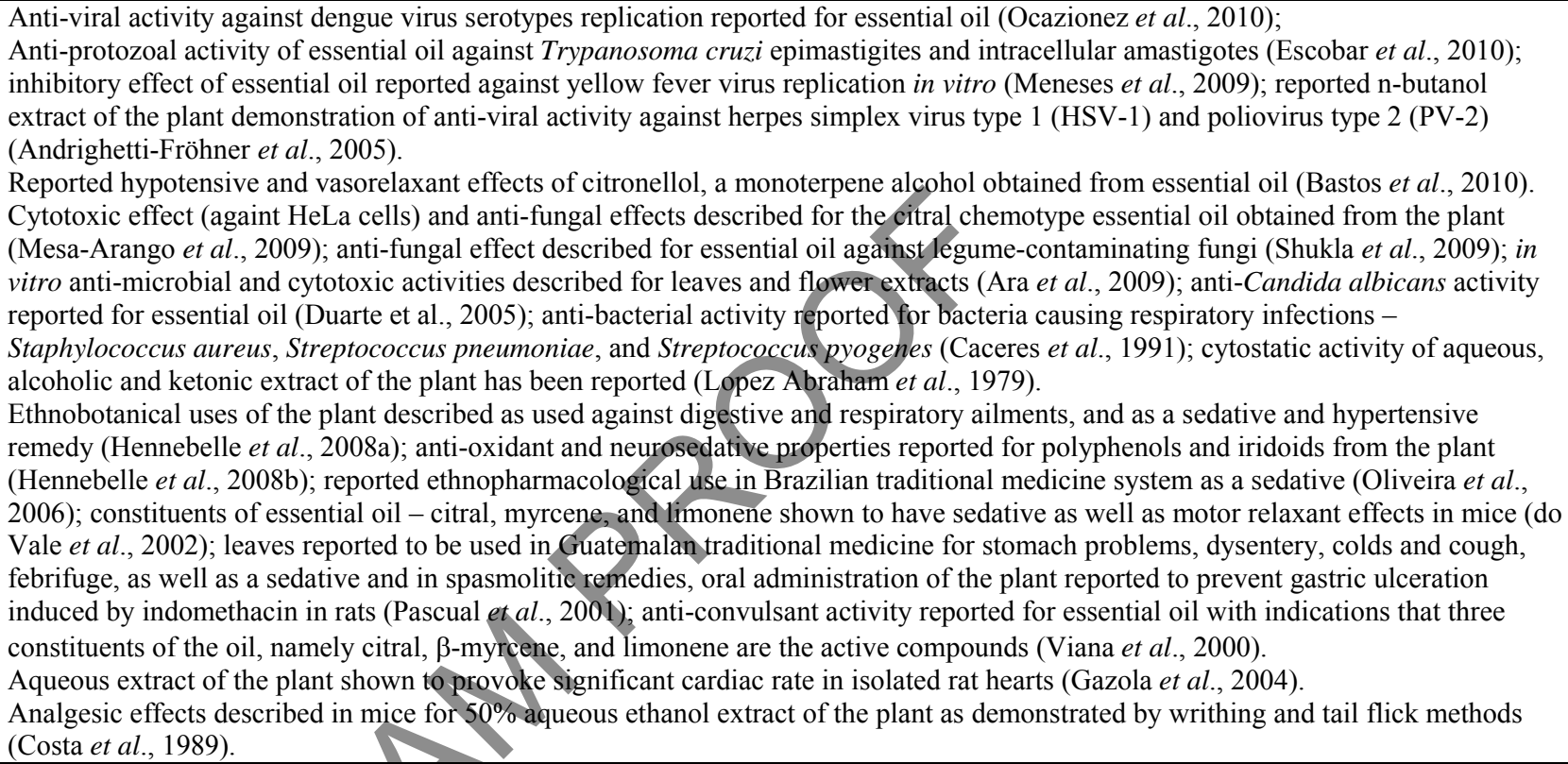 \\
\hline Lippia nodiflora (L.) Michx. & $\begin{array}{l}\text { Anti-inflammatory property exhibited by cyclo-pentano phenanthrenol isolated from the plant (Balakrishnan et al., 2010); anti- } \\
\text { inflammatory and antinociceptive activities reported for methanolic extract of leaves (Ahmed et al., 2004). } \\
\text { The plant is one of the components of the Indian drug, Anna Pavala Sindhooram, used in traditional Indian medicine for the prevention } \\
\text { and reversal of the atheroselerotic disease process (Shanmugasundaram et al., 1983). }\end{array}$ \\
\hline Nyctanthes arbor tristis L. & $\begin{array}{l}\text { Larvicidal activity of leaves and flowers extracts demonstrated against the mosquito species - Aedes aegypti, Culex quinquefasciatus, } \\
\text { and Anopheles stephensi (Mathew et al., 2009). } \\
\text { Reported tranquilizing, anti-histaminic and purgative activity of leaf extract, notably a decoction of leaves is used in Ayurvedic system } \\
\text { of medicine for treatment of sciatica, arthritis, fevers, painful conditions, and as laxative (Saxena et al., 2002). } \\
\text { Anti-bacterial and cytotoxic activity reported for extracts of flowers (Khatune et al., 2001). } \\
\text { Immunostimulant activity reported for } 50 \% \text { ethanolic extract of seeds, flowers, and leaves, which are likely to play roles in the plants' } \\
\text { traditional uses as an anti-amoebic, anti-leishmanial, and anti-viral agent (Puri et al., 1994). } \\
\text { Analgesic and anti-pyretic activity reported for leaf extract (Saxena et al., 1987); anti-inflammatory activity reported for leaf extract } \\
\text { against inflammatory edema produced by different phlogistic agents like carrageenin, formalin, histamine, 5-hydroxytryptamine and } \\
\text { hyaluronidase (Saxena et al., 1984). }\end{array}$ \\
\hline Premna integrifolia L. & $\begin{array}{l}\text { Hypoglycemic activity reported of } 95 \% \text { ethanolic extracts of plants in alloxan-diabetic rats (Kar et al., 2003); hypoglycemic activity } \\
\text { reported for plant extract in streptozotocin-induced type } 1 \text { and type } 2 \text { diabetic rats (Alamgir et al., 2001). }\end{array}$ \\
\hline
\end{tabular}


edema, cancer, diabetes, and boils, while leaves were used for treatment of skin lesions on children's throat, to remove scars from face and body, skin rash, whooping cough, allergy, and abscesses. The stems of the same plant were used for treatment of eczema, itches, and toothache. A combination of leaves and roots was used for treatment of diseases of the fetus, while a combination of leaves and bark was used for treatment of skin disorders.

Although only 13 Verbenaceae family plants were used by the folk medicinal practitioners, a wide variety of diseases were treated. Among the most frequent diseases treated were skin diseases, gastrointestinal disorders, respiratory tract disorders, rheumatoid arthritis, fever, hepatic disorders like jaundice, sexually transmitted diseases, malaria, helminthiasis, and nerve disorders. Other diseases treated with Verbenaceae family plants included heart problems, cancer, edema, measles, allergy, pain, tuberculosis, menstrual problems, herpes, night blindness, sexual disorders, hypertension, cuts and wounds, fracture or sprain, snake bite, scorpion bite, dog bite, rheumatic fever, dengue fever, head lice, nausea, vomiting, urinary tract problems, leukorrhea, hepatitis, fistula, and tetanus. Of the 13 Verbenaceae family plants used, 8 plants were used to treat skin diseases, 7 plants for treatment of gastrointestinal disorders, and 5 plants each for treatment of respiratory tract infections, rheumatoid arthritis, fever, and malaria. A plant may be used for treatment of both human and cattle diseases, e.g. Clerodendrum viscosum, which while used for treatment of various human ailments was also used for treatment of colic in cattle.

Regarding tribal usage, Clerodendrum viscosum was the most frequently used plant by various tribes, including the Chak, Garo, Manipuri, Marma, Santal, and Tripura tribes. The plant next most frequently used by various tribes was Clerodendrum indicum, which was used by the Garo, Rakhain, and Tripura tribes. The ailment(s) treated by any tribe with a particular plant was not necessarily the same as other tribes or the Kavirajes belonging to the mainstream population. To cite just one example, Clerodendrum indicum was used by the Garo tribe for skin rashes, but used by the Rakhain tribe for eczema, itches, and toothache. While it may be argued that skin rashes, itches and eczema are all skin disorders, nevertheless the use of the plant for treatment of toothache was unique to the Rakhain tribe. The Rakhain tribe also used the plant for treatment of gastrointestinal problems, respiratory problems like coughs and asthma, as well as swellings in any portion of the body. Notably the mainstream Kavirajes used the same plant or plant parts for treatment of ailments like cold, asthma, respiratory problems, bloating, tuberculosis, diseases of the fetus, excessive menstrual bleeding, sexually transmitted diseases, skin and soft tissue infections, edema, and rheumatoid arthritis. Thus while a common feature may be noted in the treatment by various tribal practitioners and Kavirajes in the treatment of skin-related disorders, overall there were more varieties in diseases treated than common uses of the plant. Duranta repens was another plant used for treatment of malaria by tribal practitioners as well as mainstream Kavirajes. But while the Garo tribal medicinal practitioners used the plant exclusively for treatment of malarial fever, mainstream Kavirajes utilized the plant as an insect repellent, and for the treatment of itches, infertility, fever, and pneumonia besides treatment of malaria.

\section{Discussion}

A number of the Verbenaceae family plants have reported bio-active properties, which validate their use in the folk medicinal system of Bangladesh. Clerodendrum inerme has been reported to have significant antinociceptive activity (Parveen et al., 2010), which might explain its use for rheumatoid arthritis, which has quite intensive pain as one of its symptoms. Antiinflammatory properties has also been reported for Clerodendrum trichotomum (Kim et al., 2009), which again can justify its folk medicinal use in Bangladesh for treatment of rheumatoid arthritis. The plant, Lippia nodiflora also reportedly has antiinflammatory and antinociceptive effects (Ahmed et al., 2004), which can be useful in the treatment of rheumatoid arthritis for which purpose the plant is used locally.

Mosquitocidal triterpenes as well as anti-plasmodial activity have been reported for Duranta repens (Nikkon et al., 2010; Ijaz et al., 2010), justifying its use as insect repellent and for treatment of malarial fever in Bangladesh. Oleanolic acid has been isolated from Lantana camara, a compound reported to have anti-plasmodial properties (Moon et al., 2007). Notably the plant is used as an anti-malarial by folk medicinal practitioners of Bangladesh. The essential oil of the plant also reportedly has anti-bacterial properties (Kurade et al., 2010), which can justify its local use for coughs, and anti-mycobacterial properties (Kirimuhuzya et al., 2009) justifying its use for treatment of tuberculosis.

Nyctanthes arbor tristis is used in Bangladesh for treatment of fever, bacterial infections, and rheumatism as well as other ailments. Validation of the plant's use can be found in the scientific literature, which describes anti-pyretic and analgesic effects of the plant (Saxena et al., 1987), as well as anti-bacterial properties of its flowers (Khatune et al., 2001).

Overall, the Verbenaceae family plants used in Bangladesh appear to have constituents with pharmacological properties, which can be useful in the treatment of bacterial and fungal infections, malaria, and pain arising from various causes including rheumatoid arthritis. The plants merit detailed studies which can prove useful in the discovery of lead compounds leading to novel and more efficacious drugs. The importance of the plants used in Bangladesh lies more so in their potential for treatment of malaria and rheumatoid arthritis, two of the most debilitating diseases affecting millions of people throughout the world.

\section{References}

1. Abdel-Hady, N.M., Abdei-Halim, A.S. and Al-Ghadban, A.M. (2005). Chemical composition and insecticidal activity of the volatile oils of leaves and flowers of Lantana camara L. cultivated in Egypt. Journal of the Egyptian Society of Parasitology. 35:687-698. 
2. Ahmad, N., Zeb, F., Ahmad, I. and Wang, F. (2009). Repenins A-D, four new antioxidative coumarinolignoids from Duranta repens Linn. Bioorganic \& Medicinal Chemistry Letters. 19:3521-3524.

3. Ahmed, F., Selim, M.S., Das, A.K. and Choudhuri, M.S. (2004). Anti-inflammatory and antinociceptive activities of Lippia nodiflora Linn. Pharmazie. 59:329-330.

4. $\quad$ Ahmed, W.S., Mohamed, M.A., El-Dib, R.A. and Hamed, M.M. (2009). New triterpene saponins from Duranta repens Linn. and their cytotoxic activity. Molecules. 14:1952-1965.

5. Alamgir, M., Rokeya, B., Hannan, J.M. and Choudhuri, M.S. (2001). The effect of Premna integrifolia Linn. (Verbenaceae) on blood glucose in streptozotocin induced type 1 and type 2 diabetic rats. Pharmazie. 56:903-904.

6. Ali-Emmanuel, N., Moudachirou, M., Akakpo, J.A. and Quetin-Leclercq, J. (2003). Treatment of bovine dermatophilosis with Senna alata, Lantana camara and Mitracarpus scaber leaf extracts. Journal of Ethnopharmacology. 86:167-171.

$7 . \quad$ Andrighetti-Fröhner, C.R., Sincero, T.C., da Silva, A.C., Savi, L.A., Gaido, C.M., Bettega, J.M., Mancini, M., de Almeida, M.T., Barbosa, R.A., Farias, M.R., Barardi, C.R. and Simões, C.M. (2005). Antiviral evaluation of plants from Brazilian Atlantic Tropical Forest. Fitoterapia. 76:374-378.

8. Ara, N., M.H., Amran, M.S., Wahid, M.I. and Ahmed, M. (2009). In vitro antimicrobial and cytotoxic activities of leaves and flowers extracts from Lippia alba. Pakistan Journal of Biological Sciences. 12:87-90.

9. Balakrishnan, G., Janakarajan, L., Balakrishnan, A. and Lakshmi, B.S. (2010). Molecular basis of the antiinflammatory property exhibited by cyclo-pentano phenanthrenol isolated from Lippia nodiflora. Immunological Investigations. 39:713-739.

10. Barre, J.T., Bowden, B.F., Coll, J.C., DeJesus, J., De La Fuente, V.E., Janairo, G.C. and Ragasa, C.Y. (1997). A bioactive triterpene from Lantana camara. Phytochemistry. 45:321-324.

11. Bastos, J.F., Moreira, I.J., Ribeiro, T.P., Medeiros, I.A., Antoniolli, A.R., De Sousa, D.P. and Santos, M.R. (2010). Hypotensive and vasorelaxant effects of citronellol, a monoterpene alcohol, in rats. Basic \& Clinical Pharmacology \& Toxicology. 106:331-337.

12. Begum, S., Zehra, S.Q., Siddiqui, B.S., Fayyaz, S. and Ramzan, M. (2008a). Pentacyclic triterpenoids from the aerial parts of Lantana camara and their nematicidal activity. Chemistry \& Biodiversity. 5:1856-1866.

13. Begum, S., Wahab, A. and Siddiqui, B.S. (2008b). Antimycobacterial activity of flavonoids from Lantana camara Linn. Natural Product Research. 22:467-470.

14. Begum, S., Wahab, A., Siddiqui, B.S. and Qamar, F. (2000). Nematicidal constituents of the aerial parts of Lantana camara. Journal of Natural Products. 63:765-767.

15. Caceres, A., Alvarez, A.V., Ovando, A.E. and Samayoa, B.E. (1991). Plants used in Guatemala for the treatment of respiratory diseases. 1. Screening of 68 plants against gram-positive bacteria. Journal of Ethnopharmacology. 31:193-208.

16. Camurça-Vasconcelos, A.L., Bevilaqua, C.M., Morais, S.M., Maciel, M.V., Costa, C.T., Macedo, I.T., Oliveira, L.M., Braga, R.R., Silva, R.A. and Vieira, L.S. (2007). Anthelmintic activity of Croton zehntneri and Lippia sidoides essential oils. Veterinary Parasitology. 148:288-294.

17. Camurça-Vasconcelos, A.L., Bevilaqua, C.M., Morais, S.M., Maciel, M.V., Costa, C.T., Macedo, I.T., Oliveira, L.M., Braga, R.R., Silva, R.A., Vieira, L.S. and Navarro, A.M. (2008). Anthelmintic activity of Lippia sidoides essential oil on sheep gastrointestinal nematodes. Veterinary Parasitology. 154:167-170.

18. Cantrell, C.L., Klun, J.A., Bryson, C.T., Kobaisy, M. and Duke, S.O. (2005). Isolation and identification of mosquito bite deterrent terpenoids from leaves of American (Callicarpa americana) and Japanese (Callicarpa japonica) beautyberry. Journal of Agricultural and Food Chemistry. 53:5948-5953.

19. Casanova, E., García-Mina, J.M. and Calvo, M.I. (2008). Antioxidant and antifungal activity of Verbena officinalis L. leaves. Plant Foods for Human Nutrition. 63:93-97.

20. Castro, O., Barrios, M., Chinchilla, M. and Guerrero, O. (1996). Chemical and biological evaluation of the effect of plant extracts against Plasmodium berghei. Revista de Biología Tropical. 44:361-367.

21. Chae, S., Kim, J.S., Kang, K.A., Bu, H.D., Lee, Y., Hyun, J.W. and Kang, S.S. (2004). Antioxidant activity of jionoside D from Clerodendron trichotomum. Biological \& Pharmaceutical Bulletin. 27:1504-1508.

22. Chae, S., Kim, J.S., kang, K.A., Bu, H.D., Lee, Y., Seo, Y.R., Hyun, J.W. and Kang, S.S. (2005). Antioxidant activity of isoacteoside from Clerodendron trichotomum. Journal of Toxicology and Environmental Health. Part A. 68:389-400.

23. Chae, S., Kang, K.A., Kim, J.S., Hyun, J.W. and Kang, S.S. (2006). Trichotomoside: a new antioxidative phenylpropanoid glycoside from Clerodendron trichotomum. Chemistry \& Biodiversity. 3:41-48.

24. Chen, J., Cantrell, C.L., Duke, S.O. and Allen, M.L. (2008). Repellency of callicarpenal and intermedeol against workers of imported fire ants (Hymenoptera: Formicidae). Journal of Economic Entomology. 101:265-271.

25. Cheruiyot, K.R., Olila, D. and Kateregga, J. (2009). In-vitro antibacterial activity of selected medicinal plants from Longisa region of Bomet district, Kenya. African Health Sciences. 9 Suppl 1:S42-S46.

26. Choi, J.H., Whang, W.K. and Kim, H.J. (2004). Studies on the anti-inflammatory effects of Clerodendron trichotomum Thunberg leaves. Archives of Pharmacal Research. 27:189-193.

27. Costa, M., Si Stasi, L.C., Kirizawa, M., Mendaçolli, S.L., Gomes, C. and Trolin, G. (1989). Screening in mice of some medicinal plants used for analgesic purposes in the state of São paulo. Part II. Journal of Ethnopharmacology. 27:25-33.

28. Dabur, R., Gupta, A., Mandal, T.K., Singh, D.D., Bajpai, V., Gurav, A.M. and Lavekar, G.S. (2007). Antimicrobial activity of some Indian medicinal plants. African Journal of Traditional, Complementary and Alternative Medicines. 4:313318. 
Rahmatullah et al., Afr J Tradit Complement Altern Med. (2011) 8(S):53-65

29. da Silva, N.A., da Silva, J.K., Andrade, E.H., Carreira, L.M., Sousa, P.J. and Maia, J.G. (2009). Essential oil composition and antioxidant capacity of Lippia schomburgkiana. Natural Product Communications. 4:1281-1286.

$30 . \quad$ Deena, M.J. and Thoppil, J.E. (2000). Antimicrobial activity of the essential oil of Lantana camara. Fitoterapia. 71:453-455.

31. De Martino, L., D’Arena, G., Minervini, M.M., Deaglio, S., Fusco, B.M., Cascavilla, N. and De Feo, V. (2009). Verbena officinalis essential oil and its component citral as apoptotic-inducing agent in chronic lymphocytic leukemia. International Journal of Immunopathology and Pharmacology. 22:1097-1104.

32. do Vale, T.G., Furtado, E.C., Santos, J.G. Jr. and Viana, G.S. (2002). Central effects of citral, myrcene and limonene, constituents of essential oil chemotypes from Lippia alba (Mill.) n.e. Brown. Phytomedicine. 9:709-714.

33. Dua, V.K., Pandey, A.C. and Dash, A.P. (2010). Adulticidal activity of essential oil of Lantana camara leaves against mosquitoes. The Indian Journal of Medical Research. 131:434-439.

34. Dua, V.K., Gupta, N.C., Pandey, A.C. and Sharma, V.P. (1996). Repellency of Lantana camara (Verbenaceae) flowers against Aedes mosquitoes. Journal of the American Mosquito Control Association. 12:406-408.

35. Duarte, M.C., Figueira, G.M., Sartoratto, A., Rehder, V.L. and Delarmelina, C. (2005). Anti-Candida activity of Brazilian medicinal plants. Journal of Ethnopharmacology. 97:305-311.

36. Escobar, P., Milena Leal, S., Herrera, L.V., Martinez, J.R. and Stashenko, E. (2010). Chemical composition and antiprotozoal activities of Colombian Lippia spp essential oils and their major components. Memórias do Instituto Oswaldo Cruz. 105:184-190.

37. Gazola, R., Machado, D., Ruggiero, C., Singi, G. Macedo Alexandre, M. (2004). Lippia alba, Melissa officinalis and Cymbopogon citratus: effects of the aqueous extracts on the isolated hearts of rats. Pharmacological Research. 50:477-480.

38. Ghosh, S., Das Sarma, M., Patra, A. and Hazra, B. (2010). Anti-inflammatory and anticancer compounds isolated from Ventilago madraspatana Gaertn., Rubia cordifolia Linn. and Lantana camara Linn. The Journal of Pharmacy and Pharmacology. 62:1158-1166.

39. Gopal, N. and Sengottuvelu, S. (2008). Hepatoprotective activity of Clerodendrum inerme against $\mathrm{CCl}_{4}$ induced hepatic injury in rats. Fitoterapia. 79:24-26.

40. Görnemann, T., Nayal, R., Pertz, H.H. and Melzig, M.F. (2008). Antispasmodic activity of essential oil from Lippia dulcis Trev. Journal of Ethnopharmacology. 117:166-169.

41. Hayashi, K., Hayashi, T., Otsuka, H. and Takeda, Y. (1997). Antiviral activity of 5,6,7-trimethoxyflavone and its potentiation of the antiherpes activity of acylovir. The Journal of Antimicrobial Chemotherapy. 39:821-824.

42. Hennebelle, T., Sahpaz, S., Joseph, H. and Bailleul, F. (2008a). Ethnopharmacology of Lippia alba. Journal of Ethnopharmacology. 116:211-222.

43. Hennebelle, T., Sahpaz, S., Gressier, B., Joseph, H. and Bailleul, F. (2008b). Antioxidant and neurosedative properties of polyphenols and iridoids from Lippia alba.Phytotherapy Research. 22:256-258.

44. Herbert, J.M., Maffrand, J.P., Taoubi,K., Augereau, J.M., Fouraste, I. and Gleye, J. (1991). Verbascoside isolated from Lantana camara, an inhibitor of protein kinase C. Journal of Natural Products. 54:1595-1600.

45. Hernández, T., Canales, M., Avila, J.G., Duran, A., Caballero, J., Romo de Vivar, A. and Lira, R. (2003). Ethnobotany and antibacterial activity of some plants used in traditional medicine from Zapotitlán de las Salinas, Puebla (México). Journal of Ethnopharmacology. 88:181-188.

46. Hossan, M.S., Hanif, A., Agarwala, B., Sarwar, M.S., Karim, M., Rahman, M.T., Jahan, R. and Rahmatullah, M. (2010). Traditional use of medicinal plants in Bangladesh to treat urinary tract infections and sexually transmitted diseases. Ethnobotany Research and Applications. 8:61-74.

47. Ijaz, F., Ahmad, N., Ahmad, I., Ul Haq, A. and Wang, F. (2010) Two new anti-plasmodial flavonoid glycosides from Duranta repens. Journal of Enzyme Inhibition and Medicinal Chemistry. (in press).

48. Iqbal, K., malik, A., Mukhtar, N., Anis, I., Khan, S.N. and Choudhary, M.I. (2004). $\alpha$-Glucosidase inhibitory constituents from Duranta repens. Chemical \& Pharmaceutical Bulletin (Tokyo). 52:785-789.

49. Jatsa, H.B., Ngo Sock, E.T., Tchuem Tchuente, L.A. and Kamtchouing, P. (2009). Evaluation of the in vivo activity of different concentrations of Clerodendrum umbellatum Poir against Schistosoma mansoni infection in mice. African Journal of Traditional Complementary and Alternative Medicines. 6:216-221.

50. Jonville, M.C., Kodja, H., Humeau, L., Fournel, J., De Mol, P., Cao, M., Angenot, L. and Frédérich, M. (2008). Screening of medicinal plants from Reunion Island for antimalarial and cytotoxic activity. Journal of Ethnopharmacology. $120: 382-386$.

51. Kang, D.G., Lee, Y.S., Kim, H.J., Lee, Y.M. and Lee, H.S. (2003). Angiotensin converting enzyme inhibitory phenylpropanoid glycosides from Clerodendron trichotomum. Journal of Ethnopharmacology. 89:151-154.

52. Kar, A., Choudhary, B.K. and Bandyopadhyay, N.G. (2003). Comparative evaluation of hypoglycaemic activity of some Indian medicinal plants in alloxan diabetic rats. Journal of Ethnopharmacology. 84:105-108.

53. Karthikeyan, M. and Deepa, K. (2010). Effect of ethanolic extract of Premna corymbosa (Burm. F.) Rottl. \& Willd. leaves in complete Freund's adjuvant-induced arthritis in Wistar albino rats. Journal of Basic and Clinical Physiology and Pharmacology. 21:15-26.

54. Kaur, J., Sharma, M., Sharma, P.D. and Bansal, M.P. (2008). Chemopreventive activity of lantadenes on two-stage carcinogenesis model in Swiss albino mice: AP-1 (c-jun), NFאB (p65) and P53 expression by ELISA and immunohistochemical localization. Molecular and Cellular Biochemistry. 14:1-8. 
55. Kembro, J.M., Marin, R.H., Zygadlo, J.A. and Gleiser, R.M. (2009). Effects of the essential oils of Lippia turbinata and Lippia polystachya (Verbenaceae) on the temporal pattern of locomotion of the mosquito Culex quinquefasciatus (Diptera: Culicidae) larvae. Parasitology Research. 104:1119-1127.

56. Khatune, N.A., Mosaddik, M.A. and Haque, M.E. (2001). Antibacterial activity and cytotoxicity of Nyctanthes arbortristis flowers. Fitoterapia. 72:412-414.

57. Kim, K.H., Kim, S., Jung, M.Y., Ham, I.H. and Whang, W.K. (2009a). Anti-inflammatory phenylpropanoid glycosides from Clerodendron trichotomum leaves. Archives of Pharmacal Research. 32:7-13.

58. Kim, Y.S. and Shin, D.H. (2004). Volatile constituents from the leaves of Callicarpa japonica Thunb. And their antibacterial activities. Journal of Agricultural and Food Chemistry. 52:781-787.

59. Kirimuhuzya, C., Wako, P., Joloba, M. and Odyek, O. (2009). The anti-mycobacterial activity of Lantana camara a plant traditionally used to treat symptoms of tuberculosis in South-western Uganda. African Health Sciences. 9:40-45.

60. Kumar, K.C.S. and Müller, K. (1999). Medicinal plants from Nepal: II. Evaluation as inhibitors of lipid peroxidation in biological membranes. Journal of Ethnopharmacology. 64:135-139.

61. Kumar, V.P., Chauhan, N.S., Padh, H. and Rajani, M. (2006). Search for antibacterial and antifungal agents from selected Indian medicinal plants. Journal of Ethnopharmacology. 107:182-188.

62. Kurade, N.P., Jaitak, V., Kaul, V.K. and Sharma, O.P. (2010) Chemical composition and antibacterial activity of essential oils of Lantana camara, Ageratum houstonianum and Eupatorium adenophorum. Pharmaceutical Biology. 48:539544.

63. Kweka, E.J., Mosha, F., Lowassa, A., Mahande, A.M., Kitau, J., Matowo, J., Mahande, M.J., Massenga, C.P., Tenu, F., Feston, E., Lyatuu, E.E., Mboya, M.A., Mndeme, R., Chuwa, G. and Temu, E.A. (2008).Ethnobotanical study of some of mosquito repellent plants in north-eastern Tanzania. Malaria Journal. 7:152.

$64 . \quad$ Lee, J.H., Lee, J.Y., Kang, H.S., Jeong, C.H., Moon, H., Whang, W.K., Kim, C.J. and Sim, S.S. (2006). The effect of acteoside on histamine release and arachidonic acid release in RBL-2H3 mast cells. Archives of Pharmacal Research. 29:508513.

65. Litaudon, M., Jolly, C., Le Callonec C., Cuong, D.D., Retailleau, P., Nosjean, O., Nguyen, V.H., Pfeiffer, B., Boutin, J.A. and Guéritte, F. (2009). Cytotoxic pentacyclic triterpenoids from Combretum sundaicum and Lantana camara as inhibitors of Bcl-xL/BakBH3 domain peptide interaction. Journal of Natural Products. 72:1314-1320.

66. Lopez Abraham, A.M., Rojas Hernandez N.M. and Jimenez Misas, C.A. (1979). Plant extracts with cytostatic properties growing in Cuba. II. Revista Cubana de Medicina Tropical. 31:105-111.

67. Machado, M., Dinis, A.M., Salgueiro, L., Cavaleiro, C., Custódio, J.B. and Sousa Mdo, C. 2010. Anti-Giardia activity of phenolic-rich essential oils: effects of Thymbra capitata, Origanum virens, Thymus zygis subsp. sylvestris, and Lippia graveolens on trophozoites growth, viability, adherence, and ultrastructure. Research. 106:1205-1215.

68. Machumi, F., Samoylenko, V., Yenesew, A.s Derese, S., Midiwo, J.O., Wiggers, F.T., Jacob, M.R., Tekwani, B.L., Khan, S.I., Walker, L.A. and Muhammad, I. (2010). Antimicrobial and antiparasitic abietane diterpenoids from the roots of Clerodendrum eriophyllum. Natural Product Communications. 5:853-858.

69. Manoharan, S., Kavitha, K., Senthil, N. and Renju, G.L. (2006). Evaluation of anticarcinogenic effects of Clerodendron inerme on 7,12-dimethylbenz(a)anthracene-induced hamster buccal pouch carcinogenesis. Singapore Medical Journal. 47:1038-1043.

70. Martin, G.J. (1995). In: Ethnobotany a 'People and Plants' Conservation Manual, Chapman and Hall, London, 268 pp.

71. Mathew, N., Anitha, M.G., Bala, T.S., Sivakumar, S.M., Narmadha, R. and Kalyanasundaram, M. (2009). Larvicidal activity of Saraca indica, Nyctanthes arbor-tristis, and Clitoria ternatea extracts against three mosquito vector species. Parasitology Research. 104:1017-1025.

72. Maundu, P. (1995). Methodology for collecting and sharing indigenous knowledge: a case study. Indigenous Knowledge and Development Monitor, 3:3-5.

73. Mendes S.S., Bomfim, R.R., Jesus, H.C., Alves, P.B., Blank, A.F., Estevam, C.S., Antoniolli, A.R. and Thomazzi, S.M. (2010). Evaluation of the analgesic and anti-inflammatory effects of the essential oil of Lippia gracilis leaves. Journal of Ethnopharmacology. 129:391-397.

74. Meneses, R., Ocazionez, R.E., Martinez, J.R. and Stashenko, E.E. (2009). Inhibitory effect of essential oils obtained from plants grown in Colombia on yellow fever virus replication in vitro. Annals of Clinical Microbiology and Antimicrobials. 8:8.

75. Mesa-Arango, A.C., Montiel-Ramos, J., Zapata, B., Durán, C., Betancur-Galvis, L. and Stashenko, E. (2009). Citral and carvone chemotypes from the essential oils of Colombian Lippia alba (Mill.) N.E. Brown: composition, cytotoxicity and antifungal activity. Memórias do Instituto Oswaldo Cruz. 104:878-884.

76. Min, Y.S., Yim, S.H., Bai, K.L., Choi, H.J., Jeong, J.H., Song, H.J., Park, S.Y., Ham, I., Whang, W.K. and Sohn, U.D. (2005). The effects of apigenin-7-O- $\beta$-D-glucuronopyranoside on reflux oesophagitis and gastritis in rats. Autonomic \& Autacoid Pharmacology. 25:85-91.

77. Misra, L.N., Dixit, A.K. and Sharma, R.P. (1997). High concentration of hepatoprotective oleanolic acid and its derivatives in Lantana camara roots. Planta Medica. 63:582.

78. Misra, N., Sharma, M., Raj, K., Dangi, A., Srivastava, S. and Misra-Bhattacharya, S. (2007). Chemical constituents and antifilarial activity of Lantana camara against human lymphatic filariid Brugia malayi and rodent filariid Acanthocheilonema viteae maintained in rodent hosts. Parasitology Research. 100:439-448. 
79. Mollik, M.A.H., Hossan, M.S., Paul, A.K., Rahman, M.T., Jahan, R. and Rahmatullah, M. (2010). A comparative analysis of medicinal plants used by folk medicinal healers in three districts of Bangladesh and inquiry as to mode of selection of medicinal plants. Ethnobotany Research and Applications. 8:195-218.

$80 . \quad$ Moon, H.I., Jung, J.C. and Lee, J. (2007). Antiplasmodial activity of triterpenoid isolated from whole plants of Viola genus from South Korea. Parasitology Research. 100:641-644.

81. Morales, G., Paredes, A., Sierra, P. and Loyola, L.A. (2008). Antioxidant activity of 50\% aqueous-ethanol extract from Acantholippia deserticola. Biological Research. 41:151-155.

82. Moyo, B., Masika, P.J., Dube, S. and Maphosa, V. (2009). An in-vivo study of the efficacy and safety of ethnoveterinary remedies used to control cattle ticks by rural farmers in the Eastern Cape Province of South Africa. Tropical Animal Health and Production. 41:1569-1576.

83. Nayak, B.S., Raju, S.S., Eversley, M. and Ramsubhag, A. (2009). Evaluation of wound healing activity of Lantana camara L. - a preclinical study. Phytotherapy Research. 23:241-245.

84. Nikkon, F., Salam, K.A., Yeasmin, T., Mosaddik, A., Khondkar, P. and Haque, M.E. (2010). Mosquitocidal triterpenes from the stem of Duranta repens. Pharmaceutical Biology. 48:264-268.

85. Ocazionez, R.E., Meneses, R., Torres, F.A. and Stashenko, E. (2010). Virucidal activity of Colombian Lippia essential oils on dengure virus replication in vitro. Memórias do Instituto Oswaldo Cruz. 105:304-309.

86. Oliveira, D.R., Leitão, G.G., Santos, S.S., Bizzo, H.R., Lopes, D., Alviano, C.S., Alviano, D.S. and Leitão, S.G. (2006). Ethnopharmacological study of two Lippia species from Oriximiná, Brazil. Journal of Ethnopharmacology. 108:103108.

87. Ono, M., Mishima, K., Yamasaki, T., Masuoka, C., Okawa, M., Kinjo, J., Ikeda, T. and Nohara, T. (2009). A new lignan glucoside from the stems of Callicarpa japonica Thunb. var. luxurians Rehd. Journal of Natural Medicines. 63:86-90.

88. Pan, P., Jia, L.Y. and Sun, Q.S. (2008). RP-HPLC determination of betulinic acid in Callicarpa macrophylla. Zhongguo Zhong Yao Za Zhi. 33:753-755.

89. $\quad$ Pan, W.D., Li, Y.J., Mai, L.T., Ohtani, K.H., Kasai, R.T., Tanaka, O. and Yu, D.Q. (1993). Studies on triterpenoid constituents of the roots of Lantana camara. Yao Xue Xue Bao. 28:40-44.

90. Pandey, R., Verma, R.K. and Gupta, M.M. (2007). High performance thin-layer chromatographic method for

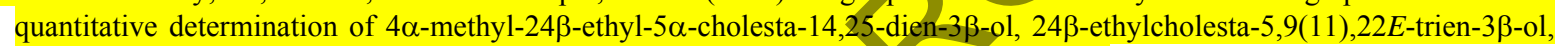
and betulinic acid in Clerodendrum inerme. Journal of Separation Science. 30:2086-2091.

91. Park, M.A. and Kim, H.J. (2007). Anti-inflammatory constituents isolated from Clerodendron trichotomum Tunberg leaves (CTL) inhibits pro-inflammatory gene expression in LPS-stimulated RAW 264.7 macrophages by suppressing NF- $\mathrm{KB}$ activation. Archives of Pharmacal Research. 30:755-760.

92. Parveen, M., Khanam, Z., Ali, M. and Rahman, S.Z. (2010). A novel lupene-type triterpene glucoside from the leaves of Clerodendrum inerme. Natural Product Research. 24:167-176.

93. Pascual, M.E., Slowing, K., Carretero, M.E. and Villar, A. (2001). Antiulcerogenic activity of Lippia alba (Mill.) N.E. Brown (Verbenaceae). Farmaco. 56:501-504

94. Puri, A., Saxena, R., Saxena, R.P., Saxena, K.C., Srivastava, V. and Tandon, J.S. (1994). Immunostimulant activity of Nyctanthes arbor-tristis L. Journal of Ethnopharmacology. 42:31-37.

95. Qamar, F., Begum, S., Raza, S.M., Wahab, A. and Siddiqui, B.S. (2005). Nematicidal natural products from the aerial parts of Lantana camara Linn. Natural Product Research. 19:609-613.

96. Rahman, A.A., Islam, S., Naim, N., Chowdhury, M.H., Jahan, R. and Rahmatullah, M. (2010) Use of medicinal plants by folk medicinal practitioners among a heterogenous population of Santals and non-Santals in two villages of Rangpur district, Bangladesh. American Eurasian Journal of Sustainable Agriculture. 4:204-210.

97. Rahmatullah, M., Haque, M.R., Islam, S.K., Jamal, F., Bashar, A.B.M.A., Ahmed, R., Ahmad, I., Jahan, R., Ahsan, S. and Chowdhury, M.H. (2010a). A survey on the use of medicinal plants by folk medicinal practitioners in three areas of Pirojpur district, Bangladesh. American Eurasian Journal of Sustainable Agriculture. 4:247-259.

98. Rahmatullah, M., Azam, M.N.K., Mollik, M.A.H., Hasan, M.M., Hassan, A.I., Jahan, R., Jamal, F., Nasrin, D., Ahmed, R., Rahman, M.M. and Khatun, M.A. (2010b). American Eurasian Journal of Sustainable Agriculture. 4:219-229.

$99 . \quad$ Rahmatullah, M., Jahan, R., Rahman, M.M., Seraj, S., Nasrin, D., Khatun, Z., Chowdhury, A.R., Azad, A.K., Khatun, M.A., Begum, R. and Jahan, F.I. (2010c). A survey of medicinal plants used by folk medicinal practitioners for treatment of gastrointestinal disorders in randomly selected areas of four districts of Bangladesh. Advances in Natural and Applied Sciences. 4:139-147.

100. Rahmatullah, M., Rahman, L., Rehana, F., Kalpana, M.A., Khatun, M.A., Jahan, R., Rahman, M.T., Bashar, A.B.M.A. and Azad, A.K. (2010d). American Eurasian Journal of Sustainable Agriculture. 4:55-64.

101. Rahmatullah, M., Islam, M.R., Kabir, M.Z., Rashid, M.H., Jahan, R., Begum, R., Seraj, S., Khatun, M.A. and Chowdhury, A.R. (2010e). Folk medicinal practices in Vasu Bihar village, Bogra district, Bangladesh. American Eurasian Journal of Sustainable Agriculture. 4:86-93.

102. Rahmatullah, M., Mollik, M.A.H., Khatun, M.A., Jahan, R., Chowdhury, A.R., Seraj, S., Hossain, M.S., Nasrin, D. and Khatun, Z. (2010f). A survey on the use of medicinal plants by folk medicinal practitioners in five villages of Boalia subdistrict, Rajshahi district, Bangladesh. Advances in Natural and Applied Sciences. 4:39-44.

103. Rahmatullah, M., Ferdausi, D., Mollik, M.A.H., Jahan, R., Chowdhury, M.H. and Haque, W.M. (2010g). A survey of medicinal plants used by Kavirajes of Chalna area, Khulna district, Bangladesh. African Journal of Traditional, Complementary and Alternative Medicines. 7:91-97. 
Rahmatullah et al., Afr J Tradit Complement Altern Med. (2011) 8(S):53-65

104. Rahmatullah, M., Rahman, M.A., Hossan, M.S., Rahman, M.T., Jahan, R. and Mollik, M.A.H. (2010h). A pharmacological and phytochemical evaluation of medicinal plants used by the harbang clan of the Tripura tribal community of Mirsharai area, Chittagong district, Bangladesh. Journal of Alternative and Complementary Medicine. 16:769-785.

105. Rahmatullah, M., Mollik, M.A.H., Rahman, M.S., Hasan, M.N., Agarwala, B. and Jahan, R. (2010i). A medicinal plant study of the Santal tribe in Rangpur district, Bangladesh. Journal of Alternative and Complementary Medicine. 16:419425 .

106. Renju, G.L., Manoharan, S., Balakrishnan, S. and Senthil, N. (2007). Chemopreventive and antilipidperoxidative potential of Clerodendron inerme (L) Gaertn in 7,12-dimethylbenz(a)anthracene induced skin carcinogenesis Swiss albino mice. Pakistan Journal of Biological Sciences. 10:1465-1470.

107. Saxena, R.S., Gupta, B. and Lata, S. (2002). Tranquilizing, antihistaminic and purgative activity of Nyctanthes arbor tristis leaf extract. Journal of Ethnopharmacology. 81:321-325.

108. Saxena, R.S., Gupta, B., Saxena, K.K., Srivastava, V.K. and Prasad, D.N. (1987). Analgesic, antipyretic and ulcerogenic activity of Nyctanthes arbor tristis leaf extract. Journal of Ethnopharmacology. 19:193-200.

109. Saxena, R.S., Gupta, B., Saxena, K.K., Singh, R.C. and Prasad, D.N. (1984). Study of anti-inflammatory activity in the leaves of Nyctanthes arbor tristis Linn. - an Indian medicinal plant. Journal of Ethnopharmacology. 11:319-330.

110. Shahat, A.A., Nazif, N.M., Abousetta, L.M., Ibrahim, N.A., Cos, P., Van Miert, S., Pieters, L. and Vlietinck, A.J. (2005). Phytochemical investigation and antioxidant activity of Duranta repens. Phytotherapy Research. 19:1071-1073.

111. Shanmugasundaram, K.R., Seethapathy, P.G. and Shanmugasundaram, E.R. (1983).Anna Pavala Sindhooram - an antiatherosclerotic Indian drug. Journal of Ethnopharmacology. 7:247-265.

112. Sharma, B. and Kumar, P. (2009). Bioefficacy of Lantana camara L. against some human pathogens. Indian Journal of Pharmaceutical Sciences. 71:589-593.

113. Sharma, M., Sharma, P.D. and Bansal, M.P. (2008). Lantadenes and their esters as potential antitumor agents. Journal of Natural Products. 71:1222-1227.

114. Shukla, N., Kumar, M., Akanksha, Ahmad, G., Rahuja, N., Singh, A.B., Srivastava, A.K., Rajendran, S.M. and Maurya, R. (2010) Tectone, a new antihyperglycemic anthraquinone from Tectona grandis leaves. Natural Product Communications. 5:427-430.

115. Shukla, R., Kumar, A., Singh, P. and Dubey, N.K. (2009). Efficacy of Lippia alba (Mill.) N.E. Brown essential oil and its monoterpene aldehyde constituents against fungi isolated from some edible legume seeds and aflatoxin B1 production. International Journal of Food Microbiology. 135:165-170.

116. Steele J.C., Warhurst, D.C., Kirby, G.C. and Simmonds, M.S. (1999). In vitro and in vivo evaluation of betulinic acid as an antimalarial. Phytotherapy Research. 13:115-119.

117. Sulaiman, M.R., Zakaria, Z.A., Chiong, H.S., Lai, S.K., Israf, D.A. and Azam Shah, T.M., (2009). Antinociceptive and anti-inflammatory effects of Stachytarpheta jamaicensis (L.) Vahl (Verbenaceae) in experimental animal models. Medical Principles and Practice. 18:272-279.

118. Tabuti, J.R. (2008). Herbal medicines used in the treatment of malaria in Budiope county, Uganda. Journal of Ethnopharmacology. 116:33-42.

119. van Baren C., Anao, I., Leo Di Pira, P., Debenedetti, S., Houghton, P., Croft, S. and Martino, V. (2006). Triterpenic acids and flavonoids from Satureja parvifolia. Evaluation of their antiprotozoal activity. Zeitschrift für Naturforschung. C, Journal of Biosciences. 61:189-192

120. Viana, G.S., do Vale, T.G., Silva, C.M. and Matos, F.J. (2000). Anticonvulsant activity of essential oils and active principles from chemotypes of Lippia alba (Mill.) N.E. Brown. Biological \& Pharmaceutical Bulletin. 23:1314-1317.

121. Weenen, H., Nkunya, M.H., Bray, D.H., Mwasumbi, L.B., Kinabo, L.S. and Kilimali, V.A. (1990). Antimalarial activity of Tanzanian medicinal plants. Planta Medica. 56:368-370.

122. Werdin González, J.O., Gutiérrez, M.M., Murray, A.P. and Ferrero, A.A. (2010). Biological activity of essential oils from Aloysia polystachya and Aloysia citriodora (Verbenaceae) against the soybean pest Nezara viridula (Hemiptera: Pentatomidae). Natural Product Communications. 5:301-306. 